\title{
The temperature of ingested water: Preference for cold water as an associative response*
}

\author{
EDWARD DEAUX and ROBERT ENGSTROM \\ Antioch College. Yellow Springs, Ohio 4538',
}

\begin{abstract}
Rats were found to prefer 12 over $36^{\prime \prime} \mathrm{C}$ water when their choice was restricted to those temperatures, but no clear preference was shown between water of $12^{\circ}$ and $24^{\circ} \mathrm{C}$ or $24^{\circ}$ and $36^{\circ} \mathrm{C}$. The hypothesis that preference for cooler Water is based on the animals" history of drinking cooler water is supported by a successful shift to preferring $36^{\circ} \mathrm{C}$ water after restricted exposure to that temperature for 15 days.
\end{abstract}

In the study of preference in the rat the temperature of ingested water has received no apparent attention. However, recent work has emphasized the importance of water temperature in the investigation of thirst and its satiation. It has been shown that when rats are maintained on a water-restriction schedule, water and food intake are positive functions of water temperature between $12^{\circ}$ and $37^{\circ} \mathrm{C}$ (approximately body temperature) (Deaux, 1973). Although Bartoshuk (1972) has suggested that the relationship between the temperature of water and its ingestion can be attributed to the taste of water at different temperatures. we have shown that drinking cold water leads to a large decrease in body temperature (Deaux \& Engstrom, 1973) and that the relationship is better explained by temperature-dependent gastric and osmotic mechanisms. In this context, it is important to establish whether rats prefer cold water, of which they drink less when no choice is available and which leads to a slow osmotic decrease, or body-temperature water, which leads to a rapid osmotic decrease of the blood and heightened consumption in the no-choice situation. The experiments reported here investigate the rats' preference for water at temperatures of $12^{\circ}, 24^{\circ}$, and $37^{\circ} \mathrm{C}$ and provide evidence relating to the source of that preference.

\section{EXPERIMENT I}

Initially, we determined the animals' preference, in a two-alternative situation, for water of different temperatures. Thirty-six degrees centigrade (slightly below body temperature) was chosen as the warmest water, $24^{\circ} \mathrm{C}$ (room temperature) as the midpoint, and $12^{\circ} \mathrm{C}$ as the lowest temperature, thus providing three values separated by equal differences on the physical temperature scale.

\section{Method}

\section{Subjects}

Thirty male Holtzman albino rats. 280 days of age at the start

*We are indebted to Professor T. I. Burns for his assistance and suggestions. of the experiment, were used. Each was housed in an individual cage with free access to Purina Lab Chow. The room in which the animals were kept was continuously lighted, and the temperature was maintained at $24^{\circ} \pm 1^{\circ} \mathrm{C}$.

\section{Apparatus}

The chambers employed for the preference tests were Hoeltge cages identical to those in which the animals were maintained. Two stainless steel drinking tubes, attached to thermally insulated water bottles, extended into the wire front of each cage. Water temperature was measured with a Yellow Springs Instrument telethermometer, Model 43TZ and Probe No. 402, inserted in the water tube orifice. Maximum temperature drift was $1.2^{\circ} \mathrm{C}$ over the 30 -min test period.

\section{Procedure}

The rats were assigned randomly to three groups $(\mathrm{N}=10)$. Prior to the test day, all animals were maintained for several weeks on a water-restriction schedule in which they received $16 \mathrm{ml}$ of room-temperature $\left(24^{\circ} \mathrm{C}\right)$ distilled water daily, rationed in four equal portions. The preference tests were conducted at the time the animals normally received their first portion; each rat was removed from its home cage and placed in a test chamber with the water bottles in place but with no food available. The animals in Group 1 were given distilled water at $12^{\circ} \mathrm{C}$ in one bottle (i.e., from one tube) and at $24^{\circ} \mathrm{C}$ in the other. Group 2 received $24^{\circ}$ and $36^{\circ} \mathrm{C}$ water, and Group 3 received the extremes, $12^{\circ}$ and $36^{\circ} \mathrm{C}$. In each group, right-left position of the alternatives was counterbalanced. Amounts consumed were determined by the weight of the water bottles at the end of the 30 -min exposure period, at which time the animals were returned to their home cages.

\section{Results}

All 30 rats demonstrated a clear preference for one of their samples, but in Groups 1 and 2, the individual choices differed between animals, as can be seen in Fig. 1, which presents the mean amount ingested at each of the temperatures for the three groups. The $24^{\circ} \mathrm{C}$ water was chosen by $60 \%$ of Group 1 and $70 \%$ of Group 2. The difference in mean intake was not significant between samples in either of these groups (Group 1: $\mathrm{F}<1.0, \mathrm{df}=1 / 9 ;$ Group 2: $\mathrm{F}=2.70, \mathrm{df}=$ $1 / 9, \mathrm{p}>.05$ ), and a test of proportions (McNemar. 1962) also failed to reveal significance. Hence, although there was a tendency for the rats in Groups 1 and 2 to choose $24^{\circ} \mathrm{C}$ water, it was not reliable. 


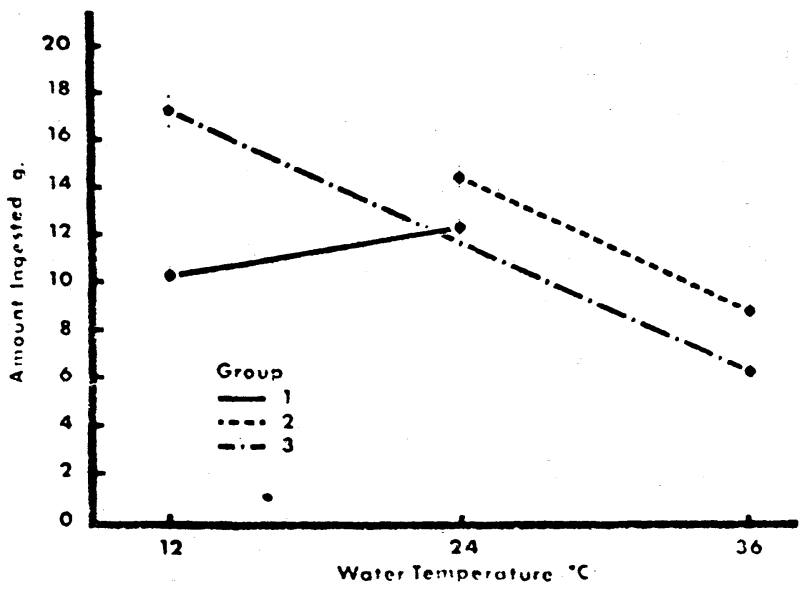

Fig. 1. Mean amounts of water ingested ( \pm standard error) during 30-min preference tests in the absence of food. Group 1 received $12^{\circ}$ and $24^{\circ} \mathrm{C}$ water; Group $2,24^{\circ}$ and $36^{\circ} \mathrm{C}$ water; and Group $3,12^{\circ}$ and $36^{\circ} \mathrm{C}$ water.

An extrapolation based on the intake of Groups 1 and 2 would predict little preference for one extreme over the other, but all 10 rats in Group 3 chose the $12^{\circ} \mathrm{C}$ sample over the $36^{\circ} \mathrm{C}$ water, and the difference in mean intake was highly significant $(F=254.64$, df $=1 / 9$, $\mathrm{p}<.0001$ ). It is of interest also that although preference varied as a function of the alternatives presented to the animals, the overall intake, with both samples combined, did not differ between groups. The mean amount of water consumed was $23.1,23.5$, and $23.4 \mathrm{~g}$ for Groups 1,2 , and 3 , respectively.

\section{Discussion}

If preference for water of a particular temperature were based on the presumably innately determined intrinsic action of cold water on tongue receptors (Mendelson \& Chillag, 1970; Kapatos \& Gold, 1972; Bartoshuk, 1972), the results of Experiment I would be expected to have shown a clear and consistent preference for cooler water in all animals. However, only when the rats were allowed to choose between $36^{\circ}$ and $12^{\circ} \mathrm{C}$ water was the preference decisive. In both groups receiving room-temperature water as one of the alternatives, there was a tendency to drink more of it than of the other choice.

This finding suggests an alternative hypothesis, which is that the stimulus complex of "water" includes its taste, its thirst-reducing property, and its temperature, which in the life of the laboratory rat usually ranges from that of tap water (i.e., approximately $10^{\circ} \mathrm{C}$ ) to room-temperature water (i.e., $24^{\circ} \mathrm{C}$ ). Stated simply, the animals have associated "coolness" with the other attributes of water, and their preference is based merely on that with which they are most familiar.

\section{EXPERIMENT II}

The second experiment was conducted to test the hypothesis proposed on the basis of the results of Experiment I. After an initial preference test between $12^{\circ}$ and $36^{\circ} \mathrm{C}$ water, animals were maintained for 15 days on one of the two temperatures exclusively, with preference tests given at the end of each week. If preference for cool water is based on innate processes, no shift in preference should occur. However, if, as we propose, preference is based on the association between water temperature and "wetness," a shift in the direction of preferring warmer water would be expected to follow the restricted consumption of only that temperature.

\section{Method}

\section{Subjects}

The Ss were 24 Holtzman male albino rats, 160 days of age at the start of the experiment. Housing and temperature conditions were identical to those in Experiment I.

\section{Procedure}

The experiment was conducted in two separate runs in which the water-restriction schedules were different but the testing procedures were the same. In the first run, 12 rats were adapted to the $16-\mathrm{ml}$ four-portion water-rationing schedule (with $24^{\circ} \mathrm{C}$ water) and then were given an initial preference test between $12^{\circ}$ and $36^{\circ} \mathrm{C}$ distilled water, using the procedure described in Experiment I. For the next 6 days, rats randomly assigned to Group Warm $(\mathrm{N}=6)$ received four $4-\mathrm{ml}$ portions of $36^{\circ} \mathrm{C}$ water daily and the animals in Group Cold received four 4-ml portions of $12^{\circ} \mathrm{C}$ water daily, all with free access to food. On Day 8 , a second preference test between $12^{\circ}$ and $36^{\circ} \mathrm{C}$ water was administered in the test chambers with no food present. For 6 days, the two groups were maintained on their respective water temperatures, and on Day 15, a third preference test was given between the two temperatures. Water consumption for each alternative was determined after every test.

In replicating this experiment, 12 rats were adapted to a water-restriction schedule on which they received access to $24^{\circ} \mathrm{C}$ distilled water for $30 \mathrm{~min}$ daily with food ad lib. The procedure for the three preference tests was identical to that employed in the first run, but on each of the days separating the tests, the animals were given $30 \mathrm{~min}$ exposure to water of the appropriate temperature rather than four equal portions.

\section{Results}

Each animal's consumption data from the preference tests were expressed as the percentage of $12^{\circ} \mathrm{C}$ water relative to total water consumption during the 30 -min test interval. There were essentially no differences between the results of the two replications, and all data were therefore combined. Figure 2 presents the percentage of cold water ingested by Group Cold and Group Warm over the three tests. It is obvious that, as in Experiment $\mathrm{I}, 12^{\circ} \mathrm{C}$ water was distinctly preferred over $36^{\circ} \mathrm{C}$ water in the first test, which for all 24 rats followed an adaptation period to $24^{\circ} \mathrm{C}$ in our laboratory. The difference was significant $(\mathrm{t}=5.63, \mathrm{df}=$ $23, p<.001$ ). Changes in preference can be seen to have occurred by the second test, as Group Warm's choice of $12^{\circ} \mathrm{C}$ water decreased to below chance (50\% cold). On the third test, the preference was almost totally reversed. 
with significantly more warm water than cold water consumed by Group Warm ( $\mathrm{t}=2.49$, df $=11, \mathrm{p}<.05)$. Group Cold, on the other hand, increased its preference for cold water only slightly over the three tests. An analysis of variance, conducted on the percentage data of both groups over all three tests, indicated a significant difference between temperatures $(F=17.53, \mathrm{df}=1 / 22$, $\mathrm{p}<.001)$, tests $(\mathrm{F}=7.15, \mathrm{df}=2 / 44, \mathrm{p}<.01)$, and a significant interaction between the two variables $(\mathrm{F}=$ $13.62, \mathrm{df}=2 / 44, \mathrm{p}<.001)$.

\section{Discussion}

The results reveal that when rats were maintained on a water temperature which was not originally preferred, their choice shifted to that temperature within a 15-day period. However, animals maintained on water of their originally preferred temperature did not substantially increase their preference for that temperature. The first finding provides strong support for the hypothesis that the usual preference for cooler water is based on the laboratory rat's experience of having been maintained on cooler water. In other words, as stated in our hypothesis, the sensation of coolness becomes associated with the other aspects of water, such as wetness and its thirst reduction. Since it is usually a part of the stimulus complex which constitutes "water" to the animal, coolness is preferred. By reconditioning the rat to associate warmth with water, the original preference was reversed in Group Warm during the 15-day maintenance period.

\section{GENERAL DISCUSSION}

The results of these two experiments indicate that the customary preference for cold water in the white rat is based on the animal's experience rather than on an innate or instinctual tendency. It is possible that the sensation of coolness is mediated by temperature-sensitive receptors in the tongue, but a more internalized mechanism such as the reduction of body temperature, which has been shown to follow cold water ingestion (Deaux \& Engstrom, 1973), is also a possible mediator. Revusky, Smith, and Chalmers (1971) found that rats' preference for flavored coffee was influenced by internal changes which accompanied the solution's ingestion but which were actually determined by intravenous infusion. And Miller, DiCara, and Wolf (1968) have shown that choice behavior in rats can be determined by subsequent antidiuretic changes resulting from injections of Pitressin. Hence, there is evidence which shows that the source of a preference can be internal, and it is unnecessary to attribute preference behavior to sensory events such as those occurring on the tongue or at the oral-pharyngeal level.

A comparison of our findings with those of previous preference studies in rats reveals the plasticity of this system, for no other attempts to shift initial preference

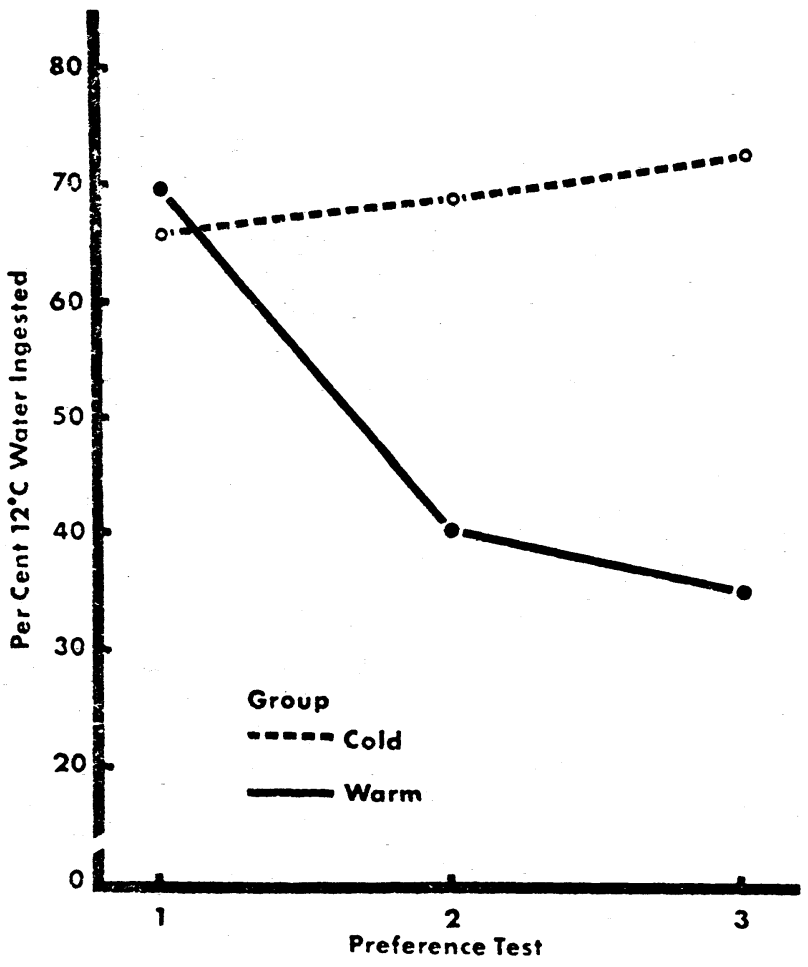

Fig. 2. Percent $12^{\circ} \mathrm{C}$ water ingested in three weekly tests of preference between $12^{\circ}$ and $36^{\circ} \mathrm{C}$ water. Group Cold was maintained exclusively on $12^{\circ} \mathrm{C}$ water between tests, and Group Warm was given only $36^{\circ} \mathrm{C}$ water.

have been as successful as this. For instance, Valle (1970), using a training procedure somewhat similar to ours, assessed rats' preference for food of different flavors and found an interaction between several variables, including the food's "attractiveness." Most importantly, some of his animals preferred a flavor other than that to which they had been habituated, a phenomenon similar to that observed by Bronson (1966), who was unable to influence rats' food preference in adulthood by restricting their diet in infancy. Working with a different sense modality, Hamm (1971) found some shift in the preference of pulsing vs steady auditory stimuli, but the success of the shift, which was minimal to begin with, was again confounded with the inherent "attractiveness" of the sound. The relative ease with which the shift occurred in our experiments, plus the absence of any apparent attractiveness of a particular water temperature, supports the hypothesis that the basis of the preference is a learned association rather than an innate or instinctual process. It also emphasizes the relative adaptiveness of this system.

Our earlier work has shown that when exposure is limited to water of one of the two temperatures used here, ingestion is a positive function of water temperature. Colder water, probably due to its relatively slow passage through the stomach, produces a less rapid decrease in blood osmolality but at the same time 
provides earlier cues of temporary (preabsorptive) satiety (Deaux, 1973). If rats were innately determined to prefer cooler water, it would mean that preabsorptive satiety was favored, even though warmer water leads ultimately to more successful rehydration. However, the results of the current experiments question this interpretation and suggest that the reason for the animals' preferring colder water in normal situations is their history of drinking colder water.

\section{REFERENCES}

Bartoshuk, L. M. Rats drink less cool water: A change in the taste of water? Science, 1972, 178, 1121.

Bronson, G. Evidence of the lack of influence of early diet on adult food preferences in rats. Journal of Comparative \& Physiological Psychology, 1966, 62, 162-164.

Deaux, E. The temperature of ingested water: Its effect on the satiation of thirst. Science, 1973, in press.

Deaux, E., \& Engstrom, R. The temperature of ingested water: Its effect on body temperature. Physiological Psychology, $1973,1,152-154$.
Hamm, C. L. Exposure learning of auditory stimuli by rats. Psychonomic Science, 1971, 23, 81-82.

Kapatos, G., \& Gold, R. M. Tongue cooling during drinking: A regulator of water intake in rats. Science, 1972, 176, 685-686.

McNemar, Q. Psychological statistics. (3rd ed.) New York: Wiley, 1962.

Mendelson, J., \& Chillag, D. Tongue cooling: A new reward for thirsty rodents. Science, 1970, 170, 1418-1421.

Miller, N. E., DiCara, L. V., \& Wolf, G. Homeostasis and reward: $T$-maze learning induced by manipulating antidiuretic hormone. American Journal of Physiology, 1968, 215, 684-686.

Revusky, S. H., Smith, N. H., \& Chalmers, D. V. Flavor preference: Effects of ingestion-contingent intravenous saline or glucose. Physiology \& Behavior, 1971, 6, 341-343.

Valle, F. P. Flavor preference in laboratory rats. Psychonomic Science, 1970, 21, 31-32.

(Received for publication March 27, 1973; revision received April 24, 1973; accepted May 1, 1973.) 